\title{
REKONSTRUKSI HIERARKI PERATURAN PERUNDANG-UNDANGAN DI INDONESIA
}

\section{RECONSTRUCTION OF THE HIERARCHY OF LEGISLATION IN INDONESIA}

\author{
Zaka Firma Aditya dan M. Reza Winata \\ Pusat Penelitian dan Pengkajian Perkara, dan Pengelolaan Perpustakaan \\ Mahkamah Konstitusi Republik Indonesia \\ Email: zaka.aditya@gmail.com \\ Naskah diterima: 11 Maret 2018 \\ Naskah direvisi: 17 Mei 2018 \\ Naskah diterbitkan: 30 Juni 2018
}

\begin{abstract}
The hierarchy of the legislation in Indonesia has been amended 4 (four) times, however still contains the juridical issues. The most common problems are related to the overlapping of the existing rules. The Law Number 12 Year 2011 as the guidance on the hierarchy of the legislation which is considered to resolve the issues on the previous law, which was also experiencing the same problem. Some of the problems contained in Law no 12 year 2011 which related to the reposition of the People's Consultative Assembly decree (MPR's decree), the unclear position of the ministerial regulations, the state organs regulations, and local regulations of village. also, as well as the content of the presidential regulation which is considered to be similar as the government regulation. This paper will discuss related: (1) the legal historical and the legal policy of the legislation's hierarchy in Indonesia and its problems; (2) the reconstruction of the legislation's hierarchy in Indonesia. The results of this paper that the establishment of the legislation's hierarchy in Indonesia each has its own political law in accordance with the regime at the time. Each hierarchy have its own problems, although the original purpose is to returned the order and to correct the ambiguity of the previous legislation. Therefore, the reconstruction of the legislation's hierarchy is important to ensure the consistency and the conformity of the norms at various levels of legislation. The reconstruction which meant here is to rearrange the hierarchy of the legislation by distinguishing between the legislation in the central levels and the regional levels.
\end{abstract}

Key words: Hierarchy; laws; regulation; problems; reconstruction

\begin{abstract}
Abstrak
Hierarki peraturan perundang-undangan di Indonesia telah diubah sebanyak 4 (empat) kali, namun masih mengandung permasalahan-permasalahan yuridis di dalamnya. Permasalahan yang paling sering terjadi berkaitan dengan tumpang tindihnya aturan-aturan yang ada. UU No. 12 Tahun 2011 tentang Pembentukan Peraturan Perundang-undangan sebagai pedoman hierarki perundang-undangan yang dianggap dapat mengatasi masalah dalam undang-undang sebelumnya, namun juga mengalami masalah yang sama. Beberapa problematika yang ada dalam UU No. 12 Tahun 2011 berkaitan dengan dikembalikannya kedudukan ketetapan MPR, tidak tegasnya kedudukan peraturan menteri, kedudukan peraturan lembaga negara, dan peraturan desa, serta materi muatan peraturan presiden yang dianggap sama dengan peraturan pemerintah. Tulisan ini akan membahas mengenai (1) legal historis dan politik hukum hierarki peraturan perundangundangan di Indonesia beserta permasalahan-permasalahannya; dan (2) rekonstruksi hierarki peraturan perundang-undangan di Indonesia. Adapun hasil penulisan ini bahwa pembentukan hierarki peraturan perundang-undangan di Indonesia memiliki politik hukum masing-masing sesuai dengan rezim pemerintahan pada saat itu. Setiap hierarki memiliki problematikanya masingmasing, meskipun tujuan awalnya sama yaitu untuk menertibkan dan memperbaiki kerancuan dari peraturan sebelumnya, sehingga rekonstruksi hierarki peraturan perundang-undangan penting
\end{abstract}


dilakukan agar menjamin konsistensi dan keselarasan norma-norma pada berbagai tingkatan peraturan perundangundangan. Adapun rekonstruksi yang dimaksud adalah dengan menata kembali hierarki peraturan perundang-undangan dengan membedakannya antara peraturan perundang-undangan tingkat pusat dan tingkat daerah.

Kata kunci: hierarki; peraturan; undangundang; permasalahan; rekonstruksi

\section{PENDAHULUAN}

Di dalam ilmu perundang-undangan dikenal adanya teori hierarki. Teori Hierarki merupakan teori yang menyatakan bahwa sistem hukum disusun secara berjenjang dan bertingkat-tingkat seperti anak tangga. Hubungan antara norma yang yang mengatur perbuatan norma lain dan norma lain tersebut disebut sebagai hubungan super dan subordinasi dalam konteks spasial. ${ }^{1}$ Norma yang menentukan perbuatan norma lain adalah superior, sedangkan norma yang melakukan perbuatan disebut norma inferior. Oleh sebab itu, perbuatan yang dilakukan oleh norma yang lebih tinggi (superior) menjadi alasan validitas keseluruhan tata hukum yang membentuk satu kesatuan. ${ }^{2}$

Di Indonesia, rantai norma hukum ini diaktualisasikan ke dalam hierarki peraturan

Jimly Asshiddiqie dan M. Ali Safa'at, Theory Hans Kelsen Tentang Hukum, Cetakan 1, Jakarta: Sekretariat Jenderal dan Kepaniteraan Mahkamah Konstitusi RI, 2006, hal. 110.

Dalam teori das doppelte rechstanilitz yang dikemukakan oleh Adolf Merkl, norma hukum pada dasarnya memiliki dua wajah. Pertama, norma hukum keatas, dimana ia bersumber dan berdasar pada norma diatasnya. Kedua, norma hukum kebawah, dimana ia juga menjadi dasar dan menjadi sumber bagi norma hukum dibawahnya. Dalam pengertian ini, maka norma hukum memiliki mas berlaku (rechtskracht) yang relative karena masa berlakunya suatu norma tergantung pada norma hukum diatasnya, sehingga apabila norma hukum diatasnya dihapus atau dicabut, maka norma hukum yang berada dibawahnya juga dihapus atau dicabut. Lihat, Maria Farida Indrati, Ilmu PerundangUndangan: Dasar dan Cara Pembentukannya, Yogjakarta: Kanisius, 1998, hal. 25. perundang-undangan sebagaimana diatur dalam Undang-Undang Nomor 12 Tahun 2011 tentang Pembentukan Peraturan PerundangUndangan (UU No. 12 Tahun 2011). Pasal 7 ayat (1) UU No. 12 Tahun 2011 menyebutkan mengenai jenis dan hierarki peraturan perundang-undangan di Indonesia, yaitu:

1. Undang-Undang Dasar Negara Republik Indonesia Tahun 1945;

2. Ketetapan Majelis Permusyawaran Rakyat;

3. Undang-Undang/Peraturan Pemerintah Pengganti Undang-Undang;

4. Peraturan Pemerintah;

5. Peraturan Presiden;

6. Peraturan Daerah Provinsi;

7. Peraturan Daerah Kabupaten/Kota.

Selanjutnya, Pasal 7 ayat (2) UU No. 12 Tahun 2011 menentukan bahwa kekuatan hukum peraturan perundang-undangan sesuai dengan hierarki sebagaimana dalam Pasal 7 ayat (1). Ini berarti bahwa Undang-Undang Dasar Negara Republik Indonesia Tahun 1945 (UUD NRI Tahun 1945) dijadikan sebagai norma dasar (basic norm) sebagaimana menurut Kelsen atau aturan dasar negara (Staatsgrundgesetz) sebagaimana pandangan Nawiaky. Oleh sebab itu, konsekuensinya adalah: pertama, UUD NRI Tahun 1945 mengesampingkan semua peraturan yang lebih rendah (berlaku asas lex superiori derogat legi inferiori) dan kedua, materi muatan dari UUD NRI Tahun 1945 menjadi sumber dalam pembentukan segala perundang-undangan, sehingga Ketetapan MPR hingga Peraturan Daerah Kabupaten/ Kota tidak boleh bertentangan dengan UUD NRI Tahun 1945. Menurut Ni'matul Huda, apabila peraturan perundang-undangan yang lebih rendah bertentangan dengan di atasnya, maka peraturan tersebut dapat dituntut untuk dibatalkan atau batal demi hukum (van rechtswegenietig). ${ }^{3}$

UU No. 12 Tahun 2011 telah memuat asas yuridis dalam pembentukan peraturan perundang-undangan di Indonesia, namun masih

Ni'matul Huda, "Kedudukan Peraturan Daerah dalam Hierarki Peraturan Perundang-Undangan”, Jurnal Hukum Vol. 13 No. 1, Januari 2006, hal. 29. 
memunculkan masalah-masalah yuridis dalam penerapannya. Pertama, UU No. 12 Tahun 2011 mengembalikan posisi/kedudukan Ketetapan MPR ke dalam hierarki peraturan perundangundangan. Padahal, dalam Undang-Undang Nomor 10 Tahun 2004 tentang Pembentukan Peraturan Perundang-Undangan (UU No. 10 Tahun 2004), kedudukan dari Ketetapan MPR telah dihapuskan dalam hierarki perundangundangan di Indonesia. Hal ini kemudian memunculkan pertanyaan dan permasalahan baru karena dengan adanya Ketetapan MPR dalam hierarki peraturan perundang-undangan, maka secara yuridis konstitusional, Ketetapan MPR tidak dapat diuji melalui sistem judicial review, baik melalui Mahkamah Konstitusi (MK) maupun Mahkamah Agung (MA). Artinya, apabila terdapat materi muatan Ketetapan MPR yang bertentangan dengan UUD NRI Tahun 1945 ataupun melanggar hak konstitusional warga negara, baik secara potensial maupun secara faktual, maka akan sangat sulit mekanisme penyelesaiannya.

Kedua, keberadaan Peraturan Presiden (Perpres) yang muatan materinya hampir sama dengan Peraturan Pemerintah dan dianggap memiliki muatan materi yang tidak menentu, sehingga berpotensi digunakan oleh presiden untuk melakukan penyalahgunaan kekuasaan (abuse of power). Ketiga, di dalam UU No. 12 Tahun 2011 juga dikenal adanya jenis peraturan perundang-undangan lainnya di luar hierarki sebagaimana ditetapkan dalam Pasal 7 ayat (1). Peraturan lainnya tersebut berupa Peraturan Majelis Permusyawaratan Rakyat (MPR), Dewan Perwakilan Rakyat (DPR), Dewan Perwakilan Daerah (DPD), Mahkamah Agung (MA), Mahkamah Konstitusi (MK), Badan Pemeriksa Keuangan (BPK), Komisi Yudisial (KY), Bank Indonesia (BI), Menteri, badan atau lembaga yang setingkat yang dibentuk dengan undang-undang atau pemerintah atas perintah undang-undang, DPRD Provinsi, Gubernur, DPRD Kabupaten/kota, Bupati/ Walikota, Kepala Desa atau setingkatnya. ${ }^{4}$

Pasal 8 ayat (1) UU No. 12 Tahun 2011 tentang Pembentukan Peraturan Perudang-undangan.
Hal ini memunculkan kebingungan (diskursus) mengenai kedudukan peraturan perundangundangan lainnya tersebut di dalam hierarki, karena dalam penerapannya, peraturan setingkat peraturan menteri justru dapat mengesampingkan peraturan daerah.

Berdasarkan permasalahan tersebut, perlu dibuat strategi rekonstruksi hierarki peraturan perundang-undangan di Indonesia. Hal ini disebabkan di dalam negara yang berdasarkan hukum, hierarki perundangundangan dijadikan sebagai legalitas dalam menyelesaikan permasalahan di bidang hukum agar tercipta keadilan dan kepastian hukum. Keberadaan hierarki peraturan perundangundangan dalam kehidupan ketatanegaraan Indonesia merupakan sebuah sistem untuk menjaga adanya konsistensi dan ketaatan asas dalam hukum positif di Indonesia. ${ }^{5}$ Larangan terdapat pertentangan antara suatu norma dengan norma yang lain, semata demi memberi jaminan kepastian hukum kepada masyarakat. Makna tata urutan atau hierarki atau tingkatan dalam tata hukum/peraturan perundangundangan adalah: ${ }^{6}$

a. Peraturan hukum atasan merupakan dasar hukum pembentukan peraturan hukum bawahan.

b. Peraturan hukum bawahan merupakan pelaksanaan peraturan hukum atasan, oleh karena itu kedudukannya lebih rendah dan materi muatannya tidak boleh bertentangan.

c. Manakala terdapat dua peraturan perundang-undangan dengan materi muatan mengatur materi sama dan dengan kedudukan sama maka berlaku peraturan perundang-undangan baru.

Dian Agung Wicaksana, "Implikasi dan Re-Eksistensi Tap MPR dalam Hierarki Peraturan Perundang-undangan terhadap Jaminan atas Kepastian Hukum yang Adil di Indonesia ", Jurnal Konstitusi, Vol. 10 No. 1, Maret 2013, hal. 151-152.

Retno Saraswati, "Perkembangan Pengaturan Sumber Hukum dan Tata Urutan Peraturan Perundang-undangan di Indonesia”, Media Hukum, Vol. IX, No. 2, April-Juni 2009, hal. 1. 
Selain itu, pembentukan peraturan perundang-undangan menjadi salah satu upaya dalam pembangunan hukum nasional. Terealisasinya pembentukan peraturan perundang-undangan yang komprehensif dan memenuhi asas-asas dan tidak saling tumpang tindih, dapat mewujudkan tegaknya wibawa hukum dalam pembangunan hukum. Adapun permasalahan yang dibahas dalam penulisan ini adalah:

1. Bagaimana legal historis dan politik Hukum pembentukan hierarki peraturan perundang-undangan di Indonesia?

2. Bagaimana rekonstruksi hierarki peraturan perundang-undangan di Indonesia?

Saat ini, terdapat beberapa literasi dalam bentuk artikel Jurnal Hukum yang telah membahas mengenai isu-isu tersebut, misalkan artikel dengan judul "Hierarki Baru Peraturan Perundang-undangan" oleh Enny Nurbaningsih dalam Jurnal Mimbar Hukum tahun 2004, lalu artikel jurnal berjudul "Kajian terhadap Jenis dan Tata Urutan Peraturan Perundang-Undang di Indonesia” oleh Syihabudin dalam Jurnal Hukum No. 24, Vol 10 tahun 2003, namun pembahasan dalam jurnal-jurnal ini masih berdasarkan hierarki perundang-undangan dahulu yang diatur UU No. 10 tahun 2004, sehingga sudah tidak relevan dengan konteks pengaturan saat ini. Adapun artikel jurnal berjudul "Problematika Hukum Undang-Undang No. 12 Tahun 2011 tentang Pembentukan Peraturan PerundangUndangan" oleh Retno Saraswati dalam Jurnal Yustisia Vol. 2, No. 3 Tahun 2013 masih sebatas mendeksripsikan permasalahan dalam pengaturan UU No. 12 tahun 2011 dan belum memberikan tawaran hierarki peraturan perundang-undangan yang baru. Untuk itu, kebaruan gagasan dalam jurnal ini mengusulkan hierarki peraturan perundang-undangan baru di Indonesia untuk menjawab permasalahanpermasalahan tersebut. Rekonstruksi hierarki ini akan menganalisis kedudukan dari setiap peraturan perundang-undangan yang saat ini berada di dalam dan di luar hierarki, yang berdasarkan doktrin-doktrin ahli dan perbandingan dengan negara lain khususnya Korea Selatan yang memiliki kemiripan hierarki peraturan perundang-undangan di Indonesia.

Tujuan dari penulisan ini adalah pertama, mengetahui legal historis dan politik hukum pembentukan peraturan perundang-undangan di Indonesia sekaligus masalah-masalahnya dari setiap rezim hierarki tersebut dan kedua, mengetahui model hierarki peraturan perundang-undangan pada masa mendatang untuk dirumuskan atau digagas oleh pembentuk undang-undang (legislator). Adapun kegunaan dari penulisan ini secara umum dapat memperluas pemahaman dan pengetahuan di bidang ilmu hukum khususnya di bidang hukum peraturan perundang-undangan. Secara khusus, tulisan ini dapat menjadi bahan masukan bagi pembuat undang-undang (legislator) dalam menyusun rancangan undang-undang tentang pembentukan peraturan perundang-undangan untuk menggantikan UU No. 12 Tahun 2011 yang saat ini masih banyak permasalahan yuridis, baik di dalam teori maupun praktiknya.

\section{LEGAL HISTORIS DAN POLITIK HUKUM PEMBENTUKAN PERATURAN PERUNDANG- UNDANGAN DI INDONESIA BESERTA PERMASALAHAN. PERMASALAHANNYA}

Berbagai literatur menyebutkan hierarki atau tata urutan peraturan perundangundangan di Indonesia telah mengalami 4 (empat) kali perubahan sejak kemerdekaan, sebagaimana diatur di dalam Ketetapan MPRS Nomor XX/MPRS/1966, Ketetapan MPR Nomor III/MPR/2000, UU No. 10 Tahun 2004, dan UU No. 12 Tahun 2011. Keempat aturan tata urutan peraturan perundang-undangan tersebut memiliki persamaan dan perbedaan yang cukup mencolok. Namun, sebenarnya hierarki peraturan perundang-undangan di Indonesia sudah dikenal sejak zaman kemerdekaan apabila ditelusuri lebih jauh.

Pada awal kemerdekaan, secara umum tidak dikenal adanya hierarki peraturan perundang-undangan. Pada masa itu dengan 
sistem pemerintahan yang executive centris, dikenal adanya peraturan dan keputusan yang tidak lazim dikenal di zaman sekarang ini seperti adanya Maklumat Presiden, Penetapan Presiden, UU darurat, UU Federal, Intruksi Presiden dan Dekrit Presiden. Selain itu, pada masa ini hanya dikenal 3 (tiga) jenis peraturan perundang-undangan di luar Undang-Undang Dasar, yaitu: (1) undang-undang; (2) Peraturan Pemerintah Sebagai Pengganti undang-undang; dan (3) Peraturan Pemerintah. Tidak terdapat jenis peraturan perundang-undangan lainnya yang disebut dan tidak ada ketentuan yang memerintahkan diaturnya jenis-jenis peraturan perundang-undangan dalam undang-undang oleh UUD 1945 (sebelum perubahan). Namun demikian, antara periode 1945-1949 juga berkembang jenis-jenis peraturan perundangundangan lainnya, seperti:

1. Penetapan Presiden;

2. Peraturan Presiden;

3. Penetapan Pemerintah;

4. Maklumat Pemerintah; dan

5. Maklumat Presiden;

Menurut A. Hamid S. Attamimi, pemakaian nama dan materi muatan dari masing-masing peraturan perundang-undangan tersebut tidak pasti, rancu, dan tidak konsisten seperti halnya penamaan "maklumat". Menurut Moch. Tolchah Mansoer, digunakannya nama "maklumat" dikarenakan pada waktu itu memang belum sempat memikirkan apakah nama produk yang dibuat oleh Presiden, Menteri, Komite Nasional, dan sebagainya. ${ }^{8}$

A. Hamid S. Attamimi, Hukum Tentang Peraturan Perundang-Undangan dan Peraturan Kebijakan (Hukum Tata Pengaturan), Pidato purna Bhakti Guru Besar Tetap, Jakarta: Fakultas Hukum Universitas Indonesia, 1993, hal. 247-257.

8 Penggunaan istilah maklumat sendiri tidak konsisten, dimana ada yang disebut Maklumat Pemerintah, Maklumat Presiden, dan Maklumat Wakil Presiden. Begitu juga dengan materi muatannya, ada yang berisi materi muatan UUD, UU, peraturan dibawah UU, atau bahkan hanya berisi pengumuman dan instruksi pemerintah, seperti Maklumat Pemerintah tanggal 28 Desember 1945 tentang Kewajiban Tentara Inggris. A. Rosyid Al Atok, Konsep Pembentukan Peraturan Perundang-undangan, Malang: Setara Press, 2015, hal. 41.
Maklumat dipakai sebagai alternatif bagi jenis peraturan perundang-undangan yang tidak dikategorikan dalam bentuk undang-undang atau peraturan pemerintah.

Selain itu, pada masa awal kemerdekaan juga masih dikenal adanya undang-undang peninggalan Belanda seperti wet, ordonantie, gemeentelijke raadverordeningen, dan besluit Beberapa di antaranya masih memiliki kekuatan hukum dan berlaku di Indonesia hingga sekarang ini, antara lain, Hinder Ordonantie (Ordonanti Gangguan/HO) berdasarkan Staatblad Nomor 226 tahun 1926, Wetboek van Strafrecht (WvS) atau Kitab Undang-Undang Hukum Pidana (KUHP) dan Burgerlijk Wetboek (BW) atau Kitab Undang-Undang Hukum Perdata (KUHpdt). Saat itu belum dikenal hierarki peraturan perundang-undangan, namun di bidang peraturan diberlakukan ketentuan umum peraturan perundang-undangan di negeri jajahan yaitu dengan dikeluarkannya Algemene Bepalingen van Wetgeving voor Indonesie Indie (AB). Di dalam Pasal 2 AB dikenal aturan umum bahwa undang-undang tidak boleh

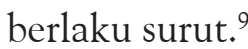

Kemudian pada2 Februari 1950, Pemerintah RI Yogjakarta menetapkan undang-undang yang mengatur tentang jenis dan hierarki peraturan perundang-undangan melalui UU No. 1 Tahun 1950 tentang Peraturan tentang Jenis dan Bentuk Peraturan yang dikeluarkan oleh Pemerintah Pusat, antara lain:

1. Undang-Undang dan Peraturan Pemerintah Pengganti Undang-Undang;

2. Peraturan Pemerintah; dan

3. Peraturan Menteri.

Dekrit Presiden 5 Juli 1959 sebagai landasan yuridis berlakunya kembali UUD 1945 membawa implikasi terhadap hierarki peraturan perundang-undangan. $\mathrm{Hal}$ ini dikarenakan jenis peraturan perundangundangan sebagaimana disebutkan dalam UUD 1945 (sebelum perubahan) yang terdiri dari undang-undang, Perppu, dan Peraturan Pemerintah dipandang belum dapat memenuhi

Ibid., hal. 2-3. 
kebutuhan. Oleh karena itu, Presiden Soekarno melalui Surat Presiden Nomor 2262/HK/1959 tertanggal 20 Agustus 1959 meminta ketua DPR-GR untuk segera mengeluarkan jenisjenis peraturan perundang-undangan lain selain yang telah disebut sebagaimana di dalam UUD 1945, antara lain: ${ }^{10}$

1. Penetapan Presiden, untuk melaksanakan Dekrit Presiden/Panglima tertinggi Angkatan Perang 5 Juli 1959;

2. Peraturan Presiden, antara lain:

a. Peraturan Presiden yang dikeluarkan berdasarkan Pasal 4 ayat (1) UUD 1945;

b. Peraturan Presiden yang untuk melaksanakan Penetapan Presiden;

3. Peraturan Pemerintah, untuk melaksanakan Peraturan Presiden;

4. Keputusan Presiden, untuk melaksanakan Peraturan Presiden dalam melakukan atau meresmikan pengangkatan-pengangkatan;

5. Peraturan Menteri, untuk mengatur sesuatu yang dibuat oleh departemen-departemen; dan

6. Keputusan Menteri, untuk melaksanakan atau meresmikan pengangkatan-pengangkatan.

Dengan dikeluarkannya berbagai peraturan perundang-undangan tersebut, menyebabkan terjadinya permasalahan dan kerancuan dalam tata urutan peraturan perundang-undangan, terutama tata urutan antara undang-undang dan penetapan presiden serta antara peraturan pemerintah dan peraturan presiden.

Penetapan presiden berdasarkan Surat Presiden kepada ketua DPR-GR tersebut pada awalnya dimaksudkan untuk melaksanakan Dekrit Presiden 5 Juli 1959 dan Peraturan Presiden dikeluarkan untuk melaksanakan UUD 1945, tetapi dalam praktiknya banyak materi muatan yang seharusnya diatur dengan undang-undang justru diatur dengan Penetapan Presiden atau dengan Peraturan Presiden atau bahkan Perppu. ${ }^{11}$ Selain itu, terdapat juga

10 Jimly Asshiddiqie, Pokok-Pokok Hukum Tata Negara Pasca Reformasi, Jakarta: PT Buana Ilmu Populer, 2007, hal. 213.

11 Soehino, Hukum Tata Negara Teknik Perundang-undangan, Yogjakarta: Liberty, 1981, hal. 6. materi muatan yang seharusnya diatur dengan Peraturan Pemerintah justru diatur melalui Peraturan Presiden dan juga banyak materi muatan dalam undang-undang yang justru diatur melalui Peraturan Presiden tersebut. ${ }^{12}$

Pada tahun 1966, Majelis Permusyawaratan Rakyat Sementara (MPRS) mengeluarkan Ketetapan MPRS Nomor XX/MPRS/1966 tentang Memorandum Dewan Perwakilan Rakyat Gotong Royong mengenai Sumber Tertib Hukum dan Tata urutan Peraturan Perundang-Undangan (Tap MPRS No. XX/ MPRS/1966), yang dilatarbelakangi adanya kerancuan-kerancuan dari sumber tertib hukum di Indonesia. Menurut Sri Soemantri, diajukannya hierarki peraturan perundangundangan dalam Tap MPRS No. XX/ MPRS/1966, dilatarbelakangi oleh adanya Dekrit Presiden 5 Juli 1959 yang telah dijadikan dasar hukum bagi Penetapan Presiden yang sederajat dengan Undang-Undang. ${ }^{13}$ Selain itu, Tap MPRS No. XX/MPRS/1966 secara tersirat memuat susunan kekuasaan dalam Negara Republik Indonesia yang semuanya bersumber pada Presiden RI (executive heavy).

Menurut Tap MPRS No. XX/MPRS/1966, tata urutan peraturan perundang-undangan sebagai berikut:

1. Undang-Undang Dasar 1945;

2. Ketetapan MPRS;

3. Undang-Undang/Peraturan Pemerintah Pengganti Undang-Undang;

4. Peraturan Pemerintah;

5. Keputusan Presiden;

6. Peraturan Menteri; dan

7. Peraturan Pelaksana Lainnya seperti:

a. Peraturan Menteri;

b. Instruksi Menteri; dan

c. Lain-lainnya

Hal tersebut menunjukkan bahwa telah ada pengaturan tata urutan peraturan perundang-undangan di Indonesia, namun pada kenyataannya masih dapat dijumpai

Ibid.

13 Riri Nazriyah, MPR RI Kajian Terhadap Produk Hukum dan Prospek di Masa Depan, Yogjakarta: FH UII, 2007, hal. 69. 
permasalahan yuridis di dalamnya. Menurut Maria Farida: ${ }^{14}$

"Keputusan Presiden tidak tepat dimasukkan dalam Hierarki Peraturan Perundang-undangan dalam Tap MPRS/XX/1966 apabila Keputusan Presiden yang dimaksud adalah yang bersifat khusus (einmalig), karena dalam Keputusan Presiden yang bersifat khusus (einmalig) normanya individual, konkret, dan sekali selesai sehingga bersifat beschikking. Padahal, norma dari suatu peraturan perundang-undangan seharusnya bersifat umum, abstrak, dan terus menerus (dauerhaftig)."

Selain itu, dimasukkannya Intruksi Menteri dalam Peraturan Perundang-undangan juga dianggap tidak tepat meskipun sebagai peraturan pelaksana. Hal ini disebabkan suatu instruksi selalu bersifat individual dan konkrit serta harus terdapat hubungan atasan dengan bawahan secara organisatoris, sedangkan sifat dari norma hukum dalam peraturan perundang-undangan adalah bersifat umum, abstrak, dan berlaku terus-menerus. ${ }^{15}$ Maria Farida juga mengkritisi bahwa dalam Tap MPRS No. XX/ MPRS/1966 tidak memasukkan Peraturan Daerah (perda) sebagai salah satu jenis peraturan perundangundangan, meskipun Perda merupakan salah satu jenis peraturan perundang-undangan dan tidak selalu merupakan peraturan pelaksana saja. ${ }^{16}$ Tidak dimasukkannya Perda dalam Tap MPRS No. XX/MPRS/1966 sebenarnya dapat dipahami karena pada masa itu sistem di Indonesia masih menganut sistem sentralistik dan belum berkembang adanya konsep desentralisasi dengan otonomi daerah.

Pasca reformasi, MPR mengeluarkan Tap MPR No. III/MPR/2000 tentang Tata Urutan Peraturan Perundang-Undangan untuk menggantikan Tap MPRS No. XX/MPRS/1966, yang dilatarbelakangi adanya keinginan untuk menertibkan dan menyelesaikan permasalahan yuridis perundang-undangan yang tidak terselesaikan dengan menggunakan Tap MPRS No. XX/MPRS/1966. Selain itu, lahirnya Tap

Maria Farida Indrati, hal. 75-77.

Ibid., hal. 79

Ibid., hal. 80.
MPR No. III/MPR/2000 juga dilatarbelakangi oleh adanya dorongan yang besar dari berbagai daerah di Indonesia untuk mendapatkan otonomi yang lebih luas berubahnya konsep otonomi daerah. ${ }^{17}$ Oleh karena itu, di dalam Tap MPR No. III/MPR/2000 ini, untuk pertama kalinya Peraturan Daerah (perda) dimasukkan ke dalam hierarki peraturan perundangundangan. Adapun bentuk dan jenis peraturan perundang-undangan yang diatur di dalam Tap MPR No. III/MPR/2000, antara lain:

1. Undang-Undang Dasar 1945;

2. Ketetapan Majelis Permusyawaratan Rakyat;

3. Undang-Undang;

4. Peraturan Pemerintah Pengganti UndangUndang;

5. Peraturan Pemerintah;

6. Keputusan Presiden; dan

7. Peraturan Daerah.

Tap MPR No. III/MPR/2000 juga menimbulkan permasalahan dalam bidang perundang-undangan. Laporan Kompendium Bidang Hukum Peraturan PerundangUndangan yang diterbitkan oleh Departemen Hukum dan HAM RI tahun 2008 menyebutkan terdapat dua permasalahan mendasar dari Tap MPR No. III/MPR/2000. ${ }^{18}$ Pertama, posisi Peraturan Pemerintah Pengganti UndangUndang (Perppu) yang terletak di bawah undang-undang, termasuk di dalamnya perbedaan materi muatan antara Perppu dan undang-undang. Ketentuan Pasal 2 Tap MPR No. III/MPR/2000 ini bertentangan dengan Pasal 22 UUD 1945 (sebelum amandemen), karena Perppu pada prinsipnya memiliki muatan materi yang sama dengan undangundang. ${ }^{19}$ Menurut Yusril Ihza Mehendra, dengan meletakkan Perppu setingkat di bawah undang-undang berarti perppu tidak

\footnotetext{
17 Dian Agung Wicaksana, "Implikasi Re-Eksistensi Tap MPR dalam Hierarki Peraturan Perundang-Undangan Terhadap Jaminan Atas Kepastian Hukum yang Adil di Indonesia”, Jurnal Konstitusi, Vol. 10 No. 1, Maret 2013, hal. 147.

18 Maria Farida, dkk., Laporan Kompendium Bidang Hukum..., Op.Cit., hal. 4.

19 Ibid.
} 
boleh bertentangan dengan undang-undang. Hal ini akan mengakibatkan kesulitan bagi pemerintah dalam mengatasi keadaan genting yang menghendaki pemerintah agar menunda/ mencabut berlakunya suatu undang-undang. Kedua, penyebutan Peraturan Daerah (perda) yang terletak di bawah keputusan presiden dan dihapuskannya keputusan menteri dalam tata urutan. $^{20}$ Selain itu, materi muatan peraturan daerah yang disebutkan dalam Tap MPR No. III/MPR/2000 dianggap terlalu luas karena tidak dibedakan antara Perda Provinsi, Perda Kabupaten/Kota, atau Peraturan Desa.

Banyaknya permasalahan yuridis dalam Tap MPR No. III/MPR/2000 tersebut menyebabkan pembaruan hukum yang terjadi pada $24 \mathrm{Mei}$ Tahun 2004 dengan disahkannya UU No. 10 Tahun 2004 yang berlaku secara efektif mulai November 2004 untuk menggantikan tata urutan peraturan perundang-undangan dalam Tap MPR No. III/MPR/2000. Pasal 7 ayat (1) UU No. 10 Tahun 2004 menentukan bahwa jenis dan hierarki peraturan perundangundangan di Indonesia sebagai berikut:

1. Undang-Undang Dasar Negara Republik Indonesia Tahun 1945;

2. Undang-Undang/Peraturan pemerintah Pengganti Undang-Undang;

3. Peraturan Pemerintah;

4. Peraturan Presiden; dan

5. Peraturan Daerah;

a. Peraturan Daerah Provinsi;

b. Peraturan Daerah Kabupaten/Kota; dan

c. Peraturan Desa/Peraturan yang setingkat.

UU No. 10 Tahun 2004 merupakan bentuk dari penyempurnaan dan perbaikan tata urutan peraturan perundang-undangan sebagaimana telah diatur dalam Tap MPR No. III/MPR/2000. Perbaikan yang dimaksud adalah: pertama, disejajarkannya kembali Perppu setingkat dengan undang-undang. Artinya, muatan materi Perppu di dalam UU No. 10 Tahun 2004 dianggap sama dengan muatan materi undang-

\footnotetext{
$20 \quad$ Maria Farida, dkk., Laporan Kompendium Bidang
} Hukum..., Loc.Cit. undang. Hal ini tidak ditemukan di dalam Tap MPR No. III/MPR/2000 yang menempatkan Perppu satu tingkat di bawah undang-undang. Kedua, kedudukan peraturan daerah di dalam UU No. 10 Tahun 2004 semakin diperinci dan dipertegas yaitu Peraturan Daerah Provinsi, Peraturan Daerah Kabupaten/Kota, dan Peraturan Desa/Peraturan yang setingkat. Ketiga, dihilangkannya kedudukan Ketetapan MPR dalam hierarki peraturan perundangundangan. Hal ini merupakan implikasi dari adanya perubahan Pasal 1 ayat (2) dan Pasal 3 dalam perubahan UUD 1945 amandemen ketiga, sehingga MPR tidak lagi memiliki kekuasaan untuk menetapkan putusanputusan yang bersifat pengaturan dalam bentuk ketetapan MPR.

Meskipun UU No. 10 Tahun 2004 lahir untuk memperbaiki permasalahan yuridis dari Tap MPR No. III/MPR/2000, namun terdapat juga beberapa masalah klasik yang dapat ditemukan. Pertama, permasalahan yang paling mencolok adalah keberadaan Peraturan Presiden (Perpres) yang materi muatannya hampir sama dengan peraturan pemerintah. Keberadaan Perpres sebenarnya sudah menjadi perdebatan lama sejak dalam Rapat Panitia Khusus (Pansus). Perdebatan yang terjadi dilandasi oleh pemikiran bahwa Presiden sebagai pemegang kekuasaan eksekutif memiliki kekuasaan yang besar di bidang legislatif karena di samping membentuk peraturan pemerintah juga dapat membentuk Perpres. Apabila dilihat dari sisi Perpres sebagai produk eksekutif (pemerintah) maka pelaksanaannya cukup dengan menggunakan Peraturan Pemerintah. Di samping itu, Perpres juga dianggap memiliki muatan materi yang tidak menentu, sehingga berpotensi digunakan untuk penyalahgunaan kekuasaan (abuse of power). Kedua, UU No. 10 Tahun 2004 dipandang memiliki ketidakjelasan dan ketidakpastian hukum dengan adanya rumusan Pasal 7 ayat (4) yang menyebutkan bahwa jenis peraturan perundang-undangan lainnya selain sebagaimana diatur dalam ayat (1), diakui keberadaannya dan memiliki kekuatan hukum mengikat sepanjang diperintahkan oleh 
peraturan perundang-undangan yang lebih tinggi.

Berdasarkan Pasal 7 UU No. 10 Tahun 2004 tersebut, pada dasarnya terdapat 2 (dua) macam peraturan perundang-undangan di Indonesia, yaitu peraturan tingkat pusat dan peraturan tingkat daerah. Menurut Maria Farida, jenis-jenis dari peraturan perundangundangan di Indonesia berdasarkan UU No. 10 Tahun 2004 dapat dikembangkan sebagai berikut: ${ }^{21}$

1. Peraturan Perundang-Undangan Tingkat Pusat Pemerintah Pengganti Undang- Undang;
a. Undang-Undang dan Peraturan
b. Peraturan Pemerintah;
c. Peraturan Presiden;
d. Peraturan Menteri;
i. Peraturan Kepala Lembaga Pemerintahan Non Departemen ;
ii. Peraturan Direktur Jenderal Departemen;

iii. Peraturan Badan Hukum Negara.

2. Peraturan Perundang-Undangan Tingkat Daerah
a. Peraturan Daerah Provinsi;
b. Peraturan/Keputusan Gubernur Kepala Daerah Provinsi;
c. Peraturan Daerah Kabupaten/ Kota;
d. Peraturan/Keputusan Bupati/Walikota Kepala Daerah Kabupaten/Kota.

Kelemahan dan permasalahan yang terdapat di dalam UU No. 10 Tahun 2004 kemudian diperbaiki dalam UU No. 12 Tahun 2011 yang menurut pembentuk undang-undang dapat dikatakan lebih sempurna dari sebelumnya. Hal ini diuraikan secara rinci di dalam Penjelasan Umum UU No. 12 Tahun 2011 bahwa lahirnya UU No. 12 Tahun 2011 dilatarbelakangi untuk menyempurnakan kelemahan-kelemahan UU No. 10 Tahun $2004 .^{22}$

\footnotetext{
$21 \quad$ Maria Farida Indrati, Ilmu Perundang-Undangan : Dasar dan Cara Pembentukannya, Yogjakarta: Kanisius, 2007, hal. 184.

22 Penjelasan umum UU No. 12 Tahun 2011 tentang Pembentukan Peraturan Perundang-Undangan.
}

Secara umum, lahirnya UU No. 12 Tahun 2011 telah memberikan penyempurnaan terhadap UU No. 10 Tahun 2004 khususnya dengan mengembalikan kedudukan dari Ketetapan MPR di dalam hierarki peraturan perundang-undangan. Ketetapan MPR diletakkan setingkat di bawah UUD NRI Tahun 1945 dan setingkat di atas undang-undang, jenis dan hierarkinya sebagai berikut:

1. Undang-Undang Dasar Negara Republik Indonesia Tahun 1945;

2. Ketetapan Majelis Permusyawaran Rakyat;

3. Undang-Undang/Peraturan Pemerintah Pengganti Undang-Undang;

4. Peraturan Pemerintah;

5. Peraturan Presiden;

6. Peraturan Daerah Provinsi; dan

7. Peraturan Daerah Kabupaten/Kota.

Menariknya, meskipun UU No. 12 Tahun 2011 dipandang lebih sempurna daripada UU No. 10 Tahun 2004, namun pada kenyataannya masih ditemukan problematika dalam penerapan hierarki peraturan perundang-undangan. Bahkan, permasalahan dalam UU No. 12 Tahun 2011 jauh lebih kompleks dibandingkan dalam UU No. 10 Tahun 2004. Pertama, UU No. 12 Tahun 2011 mengembalikan kembali kedudukan Ketetapan MPR dalam hierarki peraturan perundangundangan. Hal ini dilatarbelakangi oleh adanya tugas konstitusional bagi MPR sebagaimana diatur dalam Pasal I Aturan Tambahan UUD 1945 (setelah amandemen) untuk melakukan peninjauan terhadap materi dan status hukum ketetapan MPRS dan Ketetapan MPR untuk diambil putusan dalam sidang MPR tahun 2003 yang kemudian dituangkan dalam Tap MPR No. I/MPR/2003. Permasalahannya, setelah amandemen UUD 1945, lahir lembaga bernama Mahkamah Konstitusi (MK) yang memiliki kewenangan konstitusional yang salah satunya menguji undang-undang terhadap Undang-Undang Dasar, sedangkan peraturan perundang-undangan di bawah undangundang terhadap undang-undang dapat diuji ke Mahkamah Agung. Artinya, dalam hierarki peraturan perundang-undangan versi UU No. 
12 Tahun 2011, Ketetapan MPR tidak dapat dilakukan pengujian, baik melalui Mahkamah Konstitusi maupun Mahkamah Agung apabila terdapat materi muatan ketetapan MPR yang bertentangan dengan UUD NRI Tahun 1945 maupun undang-undang dan peraturan di bawahnya yang bertentangan dengan ketetapan MPR.

Kedua,UUNo.12Tahun2011jugamengenal adanya jenis peraturan perundang-undangan lainnya di luar hierarki sebagaimana dalam Pasal 7 ayat (1). Peraturan lainnya tersebut berupa Peraturan Majelis Permusyawaratan Rakyat, Dewan Perwakilan Rakyat, Dewan Perwakilan Daerah, Mahkamah Agung, Mahkamah Konstitusi, Badan Pemeriksa Keuangan, Komisi Yudisial, Bank Indonesia, Menteri, badan atau lembaga yang setingkat yang dibentuk dengan undang-undang atau pemerintah atas perintah undang-undang, DPRD Provinsi, Gubernur, DPRD Kabupaten/kota, Bupati/Walikota, Kepala Desa atau setingkatnya. Peraturanperaturan ini tidak memiliki kedudukan secara pasti dalam hierarki peraturan perundangundangan, sehingga seringkali memunculkan kerancuan dan pertentangan dengan peraturan perundang-undangan lainnya. Misalnya, sebagai dasar hukum, akan sangat sulit menentukan kedudukan yang lebih tinggi antara Peraturan Bank Indonesia dengan Peraturan Pemerintah. Karena dalam praktiknya, Peraturan Pemerintah Nomor 29 Tahun 1999 mengatur dengan memperbolehkan pihak asing membeli maksimal 99\% saham di Bank Lokal, sedangkan dalam Peraturan Bank Indonesia Nomor 14/8/ $\mathrm{PBI} / 2012$ mengatur bahwa pihak asing hanya dapat membeli maksimal 40\% saham di bank lokal. ${ }^{23}$

Ketiga, kedudukan Peraturan Menteri yang secara hierarki tidak termasuk ke dalam Pasal 7 ayat (1) UU No. 12 Tahun 2011, akan tetapi menurut Pasal 8 ayat (2) UU No. 12 Tahun 2011 Peraturan Menteri diakui keberadaannya dan mempunyai kekuatan hukum mengikat sepanjang diperintahkan oleh peraturan perundang-undangan yang lebih tinggi atau

23 Retno Saraswati, hal. 101. dibentuk berdasarkan kewenangan. Hal ini menimbulkan kerancuan yang dalam praktiknya seringkali terdapat banyak pengabaian, yaitu banyak daerah yang membentuk Peraturan Daerah tidak mengacu pada Peraturan Menteri. Bahkan, tidak sedikit Pemerintah Daerah yang sengaja mengabaikan Peraturan Menteri dalam pembentukan Peraturan Daerah dengan alasan tidak jelasnya posisi Peraturan Menteri dalam hierarki sebagaimana diatur UU No. 12 Tahun 2011.

Keempat, kedudukan Peraturan Daerah Kabupaten/Kota di bawah Peraturan Daerah Provinsi dalam hierarki peraturan perundangundangan yang memunculkan pertanyaan yuridis apakah pembentukan Peraturan Daerah Kabupaten/Kota harus didahului adanya pembentukan Peraturan Daerah Provinsi atau tidak. Kelima, kedudukan Peraturan Desa yang tidak dicantumkan dalam hierarki peraturan perundang-undangan. Padahal, Undang-Undang Nomor 6 Tahun 2014 tentang Desa (UU No. 6 Tahun 2014) juga telah mengamanatkan bahwa Desa memiliki kewenangan untuk menyusun Peraturan Desa. Pasal 69 ayat (1) UU No. 6 Tahun 2014 menetapkan bahwa terdapat 3 (tiga) jenis peraturan di Desa terdiri dari Peraturan Desa, Peraturan Bersama Kepala Desa, dan Peraturan Kepala Desa. Berdasarkan 3 (tiga) jenis peraturan tersebut, hanya 2 (dua) yang wajib diundangkan dalam Lembaran Desa dan Berita Desa oleh Sekretaris Desa yaitu Peraturan Desa dan Peraturan Kepala Desa. Artinya, secara teoritis, berdasarkan karakteristik, pembentukan, dan pengundangannya, maka Peraturan Desa termasuk ke dalam kategori peraturan perundang-undangan (regeling regel).

\section{REKONSTRUKSI PERATURAN \\ HIERARKI UNDANGAN DI INDONESIA}

Menurut A. Hamid S. Attamimi yang mengutip Juridish woordenboek ${ }^{24}$, kata perundang-undangan (wetgeving) mengandung

S. J. Fockema Andrea, Rechtsgeleerd Handwoordenboek, Groningen/Batavia: J.B. Wolter, 1948. 
dua macam arti, yaitu: pertama, proses pembentukan peraturan-peraturan negara dari jenis yang tertinggi yaitu undang-undang (wet) sampai yang terendah yang dihasilkan secara atribusi atau delegasi dari kekuasaan perundang-undangan (wetgevendemacht); kedua, keseluruhan produk peraturan-peraturan negara tersebut. ${ }^{25}$ Oleh sebab itu, peraturan perundang-undangan merupakan keseluruhan peraturan yang berhubungan dengan undangundang dan bersumber pada kekuasaan legislatif. ${ }^{26}$ Sementara itu, menurut Bagir Manan, apabila dikaitkan dengan isinya maka peraturan perundang-undangan merupakan keseluruhan kaidah hukum tertulis yang dibuat oleh lembaga yang berwenang yang berisi aturan tingkah laku yang bersifat abstrak dan mengikat secara umum. ${ }^{27}$ Peraturan-peraturan bersifat umum-abstrak menurut Maria Farida disebut dengan algemeen verbindende voorschrift yang meliputi de Supranationale algemeen verbindende voorschrift, Wet, AmvB, de ministeriale verordening, de gemeentelijke raadverordeningen, de provinciale staten verordeningen. ${ }^{28}$

Pendapat yang sama juga disampaikan oleh P. J. P. Tak dalam bukunya yang berjudul Rechsvorming in Netherland sebagaimana dikutip oleh Bagir Manan, yang mengartikan perundang-undangan sebagai keputusan tertulis yang dikeluarkan oleh pejabat yang berwenang yang berisi aturan yang bersifat mengikat umum. ${ }^{29} \mathrm{~T}$. J. Buys juga memberikan pengertian peraturan perundang-undangan sebagai peraturan-peraturan yang mengikat secara umum (algemeen bindende voorschriften), sedangkan J. H. A. Logemann memandang

\footnotetext{
25 A. Hamid S. Attamimi, Hukum Tentang Peraturan Perundang-Undangan..., Op.Cit., hal. 7.

Ibid., hal. 8.

27 Bagir Manan, Teori dan Politik Konstitusi, Jakarta: Dirjen DIKTI, 2000, hal. 136.

28 Maria Farida Indrati, Kedudukan dan Materi Muatan Peraturan Pemerintah Pengganti Undang-Undang, Peraturan Pemerintah dan Keputusan Presiden dalam Penyelenggaraan Pemerintahan Negara di Republik Indonesia, Jakarta: Disertasi Fakultas Hukum Universitas Indonesia, 2002, hal. 146.

29 Bagir Manan, Dasar-Dasar Perundang-undangan di Indonesia, Jakarta: Ind. Hill, 1992, hal. 3.
}

peraturan perundang-undangan tidak hanya berlaku umum tetapi juga berdaya laku keluar (naar buiten werkende voorschriften). ${ }^{30}$ Oleh karena itu, dapat ditarik benang merah bahwa peraturan perundang-undangan adalah wujud kehendak dari pemegang kekuasaan tertinggi yang bedaulat, maka peraturan perundangundangan merupakan hukum tertinggi dan satu-satunya sumber hukum. ${ }^{31}$

Secara umum, Konstitusi Indonesia mengatur jenis-jenis peraturan perundangundangan meskipun secara limitatif. Sebelum adanya amandemen UUD 1945, diatur jenisjenis peraturan peundang-undangan berupa; undang-undang [Pasal 5 ayat (1)], Peraturan Pemerintah sebagai Pengganti UndangUndang (Pasal 22), dan Peraturan Pemerintah [Pasal 5 ayat (2)]. Meskipun demikian, di luar ketiga jenis peraturan perundang-undangan tersebut terdapat juga berbagai maklumat yang mengandung muatan peraturan perundangundangan. Sementara itu, setelah adanya amandemen UUD 1945, terdapat perluasan jenis-jenis peraturan perundang-undangan yaitu tidak hanya dikenal undang-undang [Pasal 20 ayat (1)], Peraturan Pemerintah sebagai Pengganti Undang-Undang (Pasal 22), dan Peraturan Pemerintah [Pasal 5 ayat (2)], melainkan juga dikenal adanya Peraturan Daerah (perda) dan peraturan lain yaitu Peraturan Kepala Daerah [Pasal 18 ayat (6)].

Apabila diperhatikan, tata urutan peraturan perundang-undangan di Indonesia mulai dari Tap MPRS No. XX/MPRS/1966, Tap MPR No. III/MPR/2000, UU No. 10 Tahun 2004, hingga UU No. 12 Tahun 2011 masing-masing difungsikan untuk menertibkan tata urutan peraturan perundang-undangan sebelumnya yang dinilai mengandung banyak permasalahan dan penuh dengan muatan materi yang saling tumpang tindih. Oleh sebab itu, apabila dikomparasikan maka dapat terlihat perubahan

30 Amiroedin Syarief, Perundang-undangan: Dasar, Jenis dan Teknis Membuatnya, Jakarta: Bina Aksara, 1987, hal. $32-$ 33.

31 Bagir Manan dan Kuntana Magnar, Beberapa Masalah Hukum Tata Negara Indonesia, Bandung: PT Alumni, 1997, hal. 248 . 
yang dilakukan melalui tambal sulam dan bongkar pasang posisi peraturan perundangundangan.

Pada Tap MPR No. III/MPR/2000, Perppu yang disejajarkan dengan undang-undang pada Tap MPRS No. XX/MPRS/1966 diturunkan derajatnya menjadi berada di bawah undangundang. Sementara itu, peraturan menteri dicabut kedudukannya dari hierarki dan peraturan pelaksana lainnya digantikan dengan peraturan daerah. Pada UU No. 10 Tahun 2004, kedudukan Perppu dikembalikan sejajar dengan undang-undang, sementara kedudukan Ketetapan MPR dihapuskan dan Keputusan Presiden diganti menjadi Peraturan Presiden. Adapun dalam UU No. 12 Tahun 2011, Ketetapan MPR dikembalikan kedudukannya dalam hierarki yaitu tepat di bawah UUD 1945 dan tepat di atas Undang-Undang.

Berdasarkan fakta tersebut, dapat diprediksi jika perubahan tata urutan peraturan perundang-undangan ke depan masih melalui mekanisme bongkar pasang peraturan perundang-undangan. Namun, yang menjadi fokus di sini bukan hanya menjadikan peraturan seperti puzzle yang dibongkar pasang, melainkan juga melihat apakah peraturan tersebut ke depannya menimbulkan kerancuan dan permasalahan atau tidak karena bisa jadi peraturan yang dulu dihapuskan kedudukannya dari tata urutan peraturan perundang-undangan masih memiliki relevansi dengan perkembangan zaman sekarang ini. Hal ini didukung juga oleh perkembangan sistem ketatanegaraan yang semakin maju. Contoh yang paling konkret, yaitu meskipun sekarang ini Peraturan Menteri tidak berada dalam susunan tata urutan peraturan perundang-undangan di UU No. 12 Tahun 2011, namun pada faktanya justru banyak dijadikan dasar hukum pembuatan Peraturan Daerah sehingga kedudukannya lebih tinggi dari perda. Hal ini tentunya akan menimbulkan kerancuan, perdebatan, dan multitafsir di masyarakat yang mengakibatkan kacaunya implementasi berbagai peraturan perundang-undangan di Indonesia.
Menurut penulis, selain kedudukan UUD NRI Tahun 1945, Undang-Undang, dan Peraturan Pemerintah yang masih harus dipertahankan, perlu juga meninjau peraturanperaturan lainnya sebagaimana dalam Pasal 8 ayat (1) UU No. 12 Tahun 2011 yaitu peraturan menteri/setingkat, peraturan gubernur/ setingkat, dan peraturan bupati/walikota, serta perlu peninjauan terhadap Ketetapan MPR dan Peraturan Presiden. UUD NRI Tahun 1945 masih tetap dipertahankan sebagai sumber hukum tertulis tertinggi ${ }^{32}$ yang menurut Hans Nawiasky disebut sebagai Staatsgrundgesetz (aturan dasar negara). Staatsgrundgesetz ini kemudian menjiwai dan mendasari peraturan di bawahnya yaitu undang-undang (formell gezetz) dan peraturan pemerintah hingga peraturan di tingkat paling bawah (verordnung en autonome satzung).

\section{Kedudukan Ketetapan MPR dan Permasalahan Yuridisnya}

Perdebatan yang sering muncul ketika berbicara mengenai hierarki peraturan perundang-undangan adalah mengenai kedudukan Ketetapan MPR, karena kedudukan Ketetapan MPR yang dalam sejarahnya timbul dan tenggelam di dalam hierarki. Hingga saat ini berdasarkan Tap MPR No. I/MPR/2003 tentang Peninjauan Kembali Materi dan Status Hukum setiap Ketetapan MPRS dan Ketetapan MPR Tahun 1960 sampai Tahun 2002 (Tap MPR No. I/MPR/2003), terdapat beberapa Ketetapan MPR yang masih dipertahankan dan berlaku di Indonesia. Oleh sebab itu, Tap MPR dianggap memiliki legitimasi tinggi

32 Terdapat perbedaan pendapat mengenai UUD 1945 termasuk peraturan perundang-udnangan ataukah tidak. A. Hamid S. Attamimi berpandangan bahwa UUD 1945 tidak termasuk ke dalam peraturan perundang-undangan karena UUD 1945 berisi Pancasila sebagaimana terdapat dalam pembukaan (preamble) dan berisi aturan-aturan pokok dasar negara yang tidak dapat dipersamakan dengan undang-undang. Lihat, A. Hamid S. Attamimi, Hukum Tentang Peraturan...., Op.Cit., p. 290. Sementara itu, Jimly Asshiddiqie berpendapat bahwa UUD 1945 beserta perubahannya merupakan jenis peraturan perundang-undangan. Lihat, Jimly Asshiddiqie, Format Kelembagaan Negara dan Pergeseran Kekuasaan Negara dalam UUD 1945, Yogjakarta: FH UII Press, 2005, hal. 29. 
berdasarkan UU No. 12 Tahun 2011 dan kedudukannya berada di atas Undang-Undang, Peraturan Pemerintah, Peraturan Presiden, hingga Peraturan Daerah. Berdasarkan Tap MPR No. I/MPR/2003 dihasilkan beberapa ketentuan berupa 8 ketetapan MPRS/MPR yang dicabut dan dinyatakan tidak berlaku; 3 Ketetapan MPRS/MPR dinyatakan berlaku dengan ketentuan; 8 Ketetapan MPRS/ MPR dinyatakan berlaku sampai dengan terbentuknya pemerintahan hasil pemilu 2004; 11 Ketetapan MPRS/MPR dinyatakan tetap berlaku sampai dibentuknya undang-undang; 5 ketetapan MPRS/MPR dinyatakan masih berlaku sampai ditetapkannya peraturan tata tertib yang baru oleh MPR hasil pemilu 2004; dan 106 Ketetapan MPRS/MPR yang tidak perlu dilakukan tindakan hukum lebih lanjut.

Menurut A. Hamid S. Attamini, Ketetapan MPR termasuk ke dalam Staatsgrundgesetz bersama UUD 1945 dan Konvensi Internasional. ${ }^{33}$ Namun, pendapat Attamimi ini lebih cocok untuk UUD 1945 (sebelum amandemen), yang memposisikan MPR sebagai lembaga tertinggi negara yang memiliki tugas memegang kedaulatan rakyat. Menurut Pasal 1 ayat (2) UUD 1945, disebutkan bahwa "kedaulatan berada ditangan rakyat dan dijalankan sepenuhnya oleh Majelis Permusyawaran Rakyat". Pelaksanaan kedaulatan rakyat secara totalitas oleh MPR menjadikan MPR memiliki kewenangan menetapkan Garis-Garis Besar Haluan Negara (GBHN) yang berkonsekuensi hukum adanya Ketetapan MPR sebagai salah satu peraturan perundang-undangan karena memuat pengaturan (regeling).

Harun Al-Rasyid berpendapat bahwa Tap MPR tidak dapat dijadikan sebagai peraturan perundang-undangan atau memuat halhal yang bersifat pengaturan (regeling), oleh karena itu Tap MPR hanya sebatas berisi

\footnotetext{
A. Hamid S. Attamimi, Peranan Keputusan Presiden Republik Indonesia dalam Penyelenggaraan Pemerintahan Negara: Suatu Studi Analisis Mengenai Keputusan Presiden yang Berfungsi Pengaturan dalam Kurun Waktu Pelita I-IV, Disertasi Hukum. Jakarta: Pascasarjana Universitas Indonesia, 1990, hal. 287.
}

penetapan (beschiking). ${ }^{34}$ Pandangan yang sama juga disampaikan oleh Mahdfud MD, bahwa memposisikan Tap MPR dalam derajat kedua di bawah UUD 1945 hanyalah tafsiran dari MPR saja, karena UUD 1945 tidak menyebutkan bahwa Tap MPR harus berisi pengaturan (regeling) dan berbentuk peraturan perundangundangan, sehingga menetapkan hanya bisa diartikan sebagai penetapan yang bersifat individual dan konkret. ${ }^{35}$

Pada dasarnya, pendapat yang menyatakan Tap MPR tidak masuk dalam jenis peraturan perundang-undangan dilatarbelakangi oleh adanya perubahan sistem ketatanegaraan pascaamandemen. Setelah amandemen, kedudukan MPR sebagai lembaga tertinggi negara dicabut dan diganti menjadi lembaga tinggi negara yang sejajar dengan Presiden, MA, MK, BPK, DPR, dan DPD. Pasca-amandemen, kedaulatan tidak lagi dilaksanakan sepenuhnya oleh MPR tetapi dilaksanakan berdasarkan Undang-Undang Dasar sebagaimana diatur dalam Pasal 1 ayat (2) UUD NRI Tahun 1945 yang menetapkan: "kedaulatan berada ditangan rakyat dan dilaksanakan menurut Undang-Undang Dasar".

Selain itu, Pasal 3 UUD NRI Tahun 1945 juga telah menghilangkan kewenangan MPR dalam menetapkan Garis-Garis Besar Haluan Negara (GBHN), sehingga dihilangkannya kewenangan MPR dalam menyusun dan menetapkan GBHN mengandung konsekuensi bahwa aturan dasar negara hanya bertumpu pada UUD NRI Tahun 1945. Meskipun demikian, MPR masih dapat menerbitkan ketetapan yang hanya bersifat menetapkan (beschiking) seperti ketetapan pengangkatan Presiden/Wakil Presiden, ketetapan memberhentikan Presiden/ Wakil Presiden, dan ketetapan menetapkan UUD NRI Tahun 1945. ${ }^{36}$

34 Moh Mahfud MD, Perdebatan Hukum Tata Negara Pasca Amandemen Konstitusi, Jakarta: Rajawali Press, 2010, hal. 32.

Ibid.

36 Irwandi, "Kedudukan Tap MPR dan Implikasinya Terhadap Hierarki Peraturan Perundang-undangan di Indonesia", Jurnal Inovatif Ilmu Hukum, Vol. 6 No. 2, 2013, hal. 95-96. 
Selanjutnya, merujuk pada teori norma yang dinyatakan oleh Hans Kelsen bahwa suatu norma memiliki kekuatan mengikat secara umum kepada orang-orang yang diaturnya, ${ }^{37}$ maka ketika Ketetapan MPR ke depannya hanya dapat menerbitkan ketetapan yang bersifat penetapan, bukan pengaturan yang mengikat secara umum, maka seharusnya Ketetapan MPR tersebut juga tidak termasuk menjadi bagian dari hierarki norma dalam perundang-undangan.

Berdasarkan pendapat-pendapat tersebut, ke depannya Ketetapan MPR tidak perlu dimasukkankembali kedalam hierarki peraturan perundang-undangan karena Ketetapan MPR materi muatannya tidak bersifat pengaturan (regeling) tetapi hanya penetapan (beschiking). Adapun Ketetapan MPR/MPRS yang memiliki muatan materi mengatur apabila merujuk pada Tap MPR No. I/MPR/2003, maka sebenarnya Ketetapan MPR yang bersifat mengatur tersebut dapat diturunkan derajatnya menjadi Undang-Undang. Hal ini mengakibatkan sebelum adanya perubahan hierarki peraturan perundang-undangan, maka terlebih dahulu sekiranya harus mengubah Ketetapan MPR/ MPRS yang bermuatan materi mengatur dan bersifat umum menjadi undang-undang.

\section{Problematika Kedudukan dan Muatan Materi Peraturan Presiden}

Keberadaan Perpres sebagai peraturan perundang-undangan tidak diatur dalam Konstitusi sebagaimana diaturnya undangundang, peraturan pemerintah, dan peraturan daerah. Namun, eksistensi Perpres sebagai peraturan telah jauh ada di awal kemerdekaan pada tahun 1946, yaitu Presiden Soekarno mengeluarkan Peraturan Presiden Nomor 1 Tahun 1946 tentang Pemberian Ampunan kepada Hukuman.

Menurut Bagir Manan, apabila dilihat dari materi, susunan, maupun bentuknya yang tersusun dalam rincian pasal-pasal, sejak awal Perpres dibentuk berupa peraturan (regeling). Sementara itu, A.K. Pringgodigdo menyatakan bahwa dalam

37 Hans Kelsen, Op.Cit., hlm. 30
Surat Direktur Kabinet Presiden kepada Perdana Menteri tertanggal 4 Juni 1952 Nomor 1750/52-P perihal Keputusan Presiden, menegaskan bahwa "terminologi Peraturan Presiden dan Penetapan Presiden adalah dari jaman Djogja jang kedua-duanja (malahan pada permulaan djaman Republik ada terminoligie pula Penetapan Pemerintah) telah diganti dengan Keputusan Presiden". 38

Selama ini, keberadaan Peraturan Presiden (Perpres) dalam hierarki peraturan perundangundangan di Indonesia merupakan hal yang cukup kontroversial dan mengundang perdebatan dalam Rapat Panitia Khusus (pansus) RUU Pembentukan Peraturan Perundangundangan yang telah disahkan menjadi UU No. 12 Tahun 2011. DPR berinisiatif menghapuskan Perpres dari daftar hierarki peraturan perundangundangan karena materi muatannya sama dengan Peraturan Pemerintah. ${ }^{39}$ Bahkan, oleh beberapa anggota DPR, Perpres dianggap memiliki materi muatan berupa beleidsregel (aturan kebijakan) sehingga tidak termasuk di dalam hierarki peraturan perundang-undangan. Selain itu, DPR juga mempertanyakan alasan Presiden perlu membuat peraturan mandiri berupa Perpres selain dapat membuat Peraturan Pemerintah, padahal dalam sistem ketatangeraan presiden merupakan pemegang kekuasaan eksekutif, bukan legislatif. ${ }^{40}$

Ada beberapa alasan mengapa DPR mengusulkan dihapuskannya Perpres dalam hierarki, antara lain: (1) Perpres dipandang sebagai aturan kebijakan (beleidsregel) yang sifatnya mengikat ke dalam unsur pemerintahan; ${ }^{41}$ (2) Perpres sebagai peraturan

38 A. K. Pringgodigdo, Surat Direktur Kabinet Presiden kepada Perdana Menteri tertanggal 4 Juni 1952 Nomor 1750/52-P Perihal Mengenai Keputusan Presiden, Jakarta, 1952, hal.1.

39 Fajri Nursyamsi, dkk., Catatan Kinerja DPR RI Tahun 2011: Legislasi Aspirasi Atau Transaksi?, Jakarta: Pusat Studi Hukum dan Kebijakan Indonesia, 2012, hal. 97.

40 Arsip dan Dokumentasi, Risalah Rapat Panitia Khusus Rancangan Undang-Undang Tentang Pembentukan Peraturan Perundang-undangan, Jakarta: DPR RI, 2010, hal. 5.

41 Arsip dan Dokumentasi, Risalah Rapat Panitia Khusus Rancangan Undang-Undang Tentang Pembentukan Peraturan Perundang-Undangan tanggal 2 Mei 2011, Jakarta: DPR RI, tidak diterbitkan, hal. 5. 
yang memuat kaidah perintah undangundang dan melaksanakan perintah Peraturan Pemerintah pada praktiknya bersifat mandiri dan tidak berisi materi yang ditetapkan; (3) UUD NRI 1945 tidak menyebutkan Perpres sebagai jenis perundang-undangan; dan (5) pelaksanaan undang-undang cukup melalui Peraturan Pemerintah. ${ }^{42}$

Terkait dengan alasan DPR yang menyebut Perpres sebagai beleidsregel, perlu sekiranya melihat detail/rincian Perpres secara keseluruhan di dalam UU No. 12 Tahun 2011. Perpres merupakan kaidah hukum tertulis yang dibuat oleh Presiden dengan perintah undang-undang yaitu Pasal 1 angka 6 UU No. 12 Tahun 2011 untuk menjalankan peraturan perundang-undangan yang lebih tinggi (sumber kewenangan delegasi) atau dalam menyelenggarakan kekuasaan pemerintahan, yang merupakan kewenangan asli Presiden dalam menyelenggarakan pemerintahan sebagaimana diamanatkan Pasal 4 ayat (1) UUD NRI 1945. Hal ini berbeda dengan beleidsregel yang memiliki karakteristik menampakan keluar suatu kebijakan tertulis dan dibentuk tanpa disertai kewenangan pembuat peraturan yang menciptakan beleidsregel itu.

Beleidsregel dibentuk berdasarkan freise ermesen yakni wewenang yang diberikan kepada pemerintah untuk mengambil tindakan guna menyelesaikan suatu masalah penting yang mendesak/tiba-tiba tetapi belum ada peraturannya. Afdeling Rechtspraak Raad van State (ARRS) merumuskan aturan kebijakan sebagai algemene bekendmaking van het beleid (suatu maklumat yang dibuat dalam rangka melaksanakan suatu kebijakan). ${ }^{43}$ Aturan Kebijakan (beleidsregel) adalah ketentuan (rules bukan law) yang dibuat oleh pemerintah sebagai administrasi negara. Presiden hanya akan membuat aturan kebijakan dalam

42 Arsip dan Dokumentasi, Risalah Rapat Panitia Khusus Rancangan Undang-Undang Tentang Pembentukan Peraturan Perundang-Undangan tanggal 13 Desember 2010, Jakarta : DPR RI, tidak diterbitkan, hal. 5.

$43 \quad$ Phillipus M. Hadjon, dkk., Pengantar Hukum Administrasi Indonesia, Yogjakarta: Gadjah Mada University Press, 2015, hal. 169. kedudukannya sebagai badan atau pejabat administrasi negara. ${ }^{44}$

Selain itu, Perpres dapat digunakan untuk membatalkan Perda, artinya kedudukan Perpres lebih tinggi daripada Perda, sedangkan beleidsregel tidak dapat digunakan untuk membatalkan Perda. Perpres dapat diujikan melalui mekanisme judicial review di Mahkamah Agung, sedangkan beleidsregel tidak dapat diujikan melalui mekanisme judicial review sehingga tidak tepat apabila menyamakan Perpres dengan beleidsregel, karena keduanya memiliki karakteristik yang jauh berbeda.

Pentingnya keberadaan Perpres sebagai suatu peraturan perundang-undangan dilatarbelakangi oleh perkembangan sistem ketatanegaraan yang menuju negara kesejahteraan (welfarestate) yang menghendaki pemerintah untuk ikut aktif mengurus berbagai kepentingan warga negaranya. Menurut A. Hamid S. Attamimi, frasa Presiden memegang kekuasaan pemerintah berarti bahwa Presiden berwenang untuk memutuskan (belissende bevoegheid) danmengatur (regelendebevoegheid). ${ }^{45}$ Dalam hal ini, Perpres merupakan kewenangan Presiden untuk mengatur agar penyelenggaraan pemerintahan dapat berjalan lancar, sehingga keberadaan Perpres merupakan atribusi dari Pasal 4 ayat (1) UUD NRI Tahun 1945. Untuk itu, apabila dikaitkan dengan teori norma yang disampaikan oleh Hans Kelsen bahwa suatu norma memiliki kekuatan mengikat secara umum kepada orang-orang yang diaturnya, ${ }^{46}$ Perpres yang memiliki kekuatan mengikat kepada masyarakat umum seharusnya tetap termasuk dalam bagian hierarki peraturan perundang-undangan.

Namun, luasnya cakupan materi Perpres sehingga ke depannya perlu adanya pembatasan ruang lingkup Perpres karena jika tidak dibatasi maka dikhawatirkan akan terjadi penyalahgunaan kewenangan dan kekuasaan. Meskipun, di dalam Pasal 13UUNo. 12 Tahun 2011 telah menegaskan

\footnotetext{
44 Ibid., hal. 161.

45 A. Hamid S, Attamimi, Peranan Keputusan Presiden..., Op.Cit., hal. 186-187.

46 Hans Kelsen, General Theory of Law, London: Oxford University Press, 1949, hal. 30
} 
bahwa muatan materi Perpres berupa: (1) materi yang diperintahkan oleh undang-undang, dan materi untuk melaksanakan perintah peraturan pemerintah, atau (2) materi untuk menyelenggarakan kekuasaan pemerintahan. Jimly Asshiddiqie menyampaikan beberapa hal yang dapat menjadi pembatasan Perpres, yaitu: ${ }^{47}$ (1) Adanya perintah oleh peraturan yang lebih tinggi; (2) Perintah dimaksud tidak harus bersifat tegas dalam arti langsung menyebutkan bentuk hukum penuangan norma hukum yang perlu diatur, asalkan perintah pengaturan tersebut tetap ada; (3) Dalam hal perintah tersebut memang sama sekali tidak ada, maka Perpres itu dapat dikeluarkan untuk maksud mengatur halhal yang benar-benar bersifat teknis administrasi pemerintahan dan semata-mata dimaksudkan untuk tujuan internal penyelenggaraan ketentuan undang-undang dan peraturan pemerintah.

\section{Kedudukan \\ Peraturan \\ Majelis \\ Permusyawaratan Rakyat, Dewan \\ Perwakilan Rakyat, Dewan Perwakilan \\ Daerah, Mahkamah Agung, Mahkamah \\ Konstitusi, dan Badan Pemeriksa Keuangan \\ Untuk mengkaji kedudukan Peraturan} Peraturan MPR, DPR, DPD, MA, MK, dan BPK dalam hierarki Peraturan Perundang-undangan, maka dapat dianalisis berdasarkan hierarki dari lembaga negara yang menerbitkannya. Jimly Asshidiqie menyatakan bahwa kelembagaan negara berdasarkan hierarkinya dapat didasarkan pada dua kriteria yang dapat dipakai, yaitu (i) kriteria hierarki bentuk sumber normatif yang menentukan kewenangannya dan (ii) kualitas fungsinya yang bersifat utama atau penunjang dalam sistem kekuasaan negara, sehingga terdapat lembaga negara yang bersifat utama atau primer (main state organ) dan bersifat sekunder atau penunjang (auxiliary state organ). ${ }^{48}$

47 Jimly Asshiddiqie dalam Ni'matul Huda dan R. Nazriyah, Teori dan Pengujian Peraturan Perundang-Undangan, Bandung: Nusamedia, 2011, hal. 109.

48 Jimly Asshidiqie, Perkembangan dan Konsolidasi LembagaLembaga Negara Pasca Reformasi, Jakarta: Sekretariat Jendral dan Kepaniteraan Mahkamah Konstitusi Republik Indonesia, 2006, hal. 105
Selanjutnya Jimly Asshidiqie memberikan konsep bahwalembaga negara utama merupakan lapis pertama yang dapat juga disebut sebagai lembaga tinggi negara, di antaranya: 1) Presiden dan Wakil Presiden; 2) Dewan Perwakilan Rakyat (DPR); 3) Dewan Perwakilan Daerah (DPD); 4) Majelis Permusyawaratan Rakyat (MPR); 5) Mahkamah Konstitusi (MK); 6) Mahkamah Agung (MA); 7) Badan Pemeriksa Keuangan (BPK). ${ }^{49}$ Berdasarkan hierarki dari lembaga negara utama ini, sebenarnya Peraturan dari lembaga negara ini juga dapat disejajarkan dengan Peraturan Presiden berdasarkan prinsip pemisahan kekuasaan dan checks and balances yaitu yang mensejajarkan ketujuh lembaga negara tersebut.

Adanya peraturan-peraturan pelaksana undang-undang dari lembaga negara utama tersebut berhubungan dengan subordinate legislations yang dianggap urgen dan terus berkembang dalam praktik negara hukum modern, sebagaimana pendapat Gary Slapper \& David Kelly, "Delegated legislation is of particular importance. Generally speaking, delegated legislation is law made by some person or body to whom Parliament has delegated its general law-making power. A validly enacted piece of delegated legislation has the same legal force and effect as the Act of Parliament under which it is enacted but, equally, it only has effect to the extent that its enabling Act authorises it". ${ }^{50}$. Hal ini juga berkaitan dengan adanya kekurangan dalam legislasi yang dilakukan oleh pembentuk undang-undang. Menurut Enrico Simanjuntak salah satu alasannya karena parlemen dan presiden tidak mempunyai cukup waktu untuk secara mendetail memberikan perhatian mengenai segala urusan teknis mengenai materi suatu undang-undang. ${ }^{51}$

Oleh karena itu, dapat dipahami bahwa Peraturan MPR, DPR, DPD, MA, MK, dan BPK

\footnotetext{
49 Ibid.

50 Slapper, Gary \& Kelly, David., The English Legal System, Sixth edition, London: Cavendish Publishing Limited, 2003. hal.63

$51 \quad$ Enrico Simanjuntak, "Kewenangan Hak Uji Materil Pada Mahkamah Agung RI", Jurnal Hukum dan Peradilan, Vol. 2 No. 3 November 2013, hal. 340-341.
} 
yang merupakan pengaturan (regeling) kepada masyarakat telah memenuhi prasyarat sebagai norma dan mengikat secara umum dalam teori hierarki norma, sehingga seharusnya diposisikan sejajar dengan Peraturan Presiden.

\section{Kedudukan Peraturan Menteri dan} Lembaga Negara Setingkat Kementerian Peraturan Menteri mendapatkan kedudukan sebagai peraturan lainnya di dalam UU No. 12 Tahun 2011. Meskipun tidak secara spesifik masuk di dalam hierarki, namun keberadaannya tetap diakui dan bahkan dalam pelaksanaannya. Peraturan Menteri justru kedudukannya lebih tinggi daripada peraturan daerah karena di era UU No. 23 Tahun 2014, Peraturan daerah dibatalkan melalui Peraturan Menteri (Permendagri). Namun, di dalam praktik yang lain, beberapa instansi pemerintahan masih menggunakan Peraturan Menteri sebagai jenis peraturan yang bersifat mengatur (regeling) dan kedudukannya lebih tinggi daripada Keputusan Menteri (beschiking).

Peraturan Menteri merupakan peraturan pusat yang dibuat oleh pemerintah pusat yang besifat pelaksanaan terhadap peraturan yang lebih tinggi dan sekaligus merupakan pelaksanaan kewenangan pusat yang memiliki kedudukan lebih tinggi daripada peraturan daerah. Oleh sebab itu, setiap penetapan peraturan daerah harus mengacu berdasarkan peraturan menteri..$^{52}$

Pembentukan peraturan menteri sendiri dilatarbelakangi pada kebijakan pemerintah yang perlu dituangkan dalam bentuk peraturan yang bersifat pelaksanaan terhadap peraturan yang lebih tinggi, oleh sebab itu Menteri atau pejabat setingkat menteri dapat diberikan kewenangan untuk membuat peraturan yang besifat pelaksanaan tersebut.

Apabila diperhatikan, pelaksanaan pembuatan peraturan menteri bersumber dari delegasi yaitu untuk menjalankan peraturan perundang-undangan yang lebih tinggi. Oleh sebab itu, peraturan menteri memiliki

52 Maria Farida dkk., Laporan Kompedium...., Op.Cit., hal. 47. karakteristik yang hampir sama dengan Perpres hanya saja peraturan menteri berada di bawah derajat Perpres. Sementara itu, peraturan di bawah peraturan menteri tersebut merupakan jenis peraturan kebijakan (beleidsregel) dan didasarkan atas asas kebebasan bertindak (beleidvrijheid atau beoorderings vrijheid), yang pelaksanaan kebijakan tersebut tidak atas dasar peraturan perundang-undangan karena pembuat peraturan kebijakan tidak mempunyai kewenangan perundang-undangan dan tidak ada kewenangan mengatur (wetgever). ${ }^{53}$

\section{Kedudukan Peraturan Gubernur, Peraturan Bupati/Walikota}

Peraturan Gubernur dan Peraturan Bupati/ Walikota juga memiliki karakteristik yang sama dengan peraturan menteri dan Perpres yaitu termasuk ke dalam peraturan yang bersumber dari delegasi. Hanya saja, kedudukan Peraturan Gubernur dan Peraturan Bupati/Walikota berada di bawah peraturan menteri karena Peraturan Gubernur dan peraturan Bupati/ Walikota merupakan peraturan yang berada di pemerintahan tingkat daerah. Peraturan Gubernur dan Peraturan Bupati/Walikota bersumber dari delegasi untuk melaksanakan peraturan perundang-undangan yang lebih tinggi. Peraturan Gubernur memiliki kedudukan lebih rendah dari Perda Provinsi tetapi lebih tinggi daripada Perda Kabupaten/Kota, sedangkan peraturan bupati/walikota memiliki kedudukan di bawah Peraturan Gubernur dan di bawah Perda Kabupaten/Kota.

Sementara itu, peraturan di bawah Gubernur, Bupati, dan Walikota yang dibuat oleh Kepala Dinas, Pejabat Eselon, dan Kepala SKPD lainnya termasuk ke dalam peraturan kebijakan (beleidsregel) ${ }^{54}$ yang tidak masuk

53 Arief Christino Soebroto, Kedudukan Hukum Peraturan/ Kebijakan dibawah Peraturan Menteri Perencanaan Pembangunan Nasional, file pdf diunduh dari www. bappenas.go.id, hal. 12

54 Di dalam kepustakaan hukum Belanda, ada beberapa istilah aturan kebijakan, antara lain pseudowetgeving (Van der hoevens), spiegelsrecht (Mannoury), dan beleidsregel (alvan Kreveld). Aturan kebijakan, banyak disebut dengan istilah peraturan kebijakan. Menurut Bagir Manan, penggunaan istilah "peraturan" dalam arti wegeving 
dalam kategori peraturan perundang-undangan. Adapun kekuatan mengikatnya beleidsregel, menurut Bagir Manan, tidak secara langsung mengikat secara hukum tetapi mengandung relevansi hukum. Maksudnya adalah Peraturan kebijakan pada dasarnya ditujukan kepada badan atau pejabat administrasi negara sendiri. Jadi yang pertama-tama melaksanakan ketentuan yang termuat dalam peraturan kebijakan adalah badan atau pejabat administrasi negara. Meskipun demikian, ketentuan tersebut secara tidak langsung akan dapat mengenai masyarakat umum. ${ }^{55}$ Apabila dianalisis menggunakan teori hierarki norma sebagaimana yang dijelaskan oleh Hans Kelsen, bahwa semua norma-norma yang telah diakui validitasnya dan mengikat secara umum memiliki jenjang, ${ }^{56}$ maka Peraturan Menteri, Peraturan Gubernur, dan Peraturan Bupati/ Walikota yang berlaku juga kepada masyarakat umum seharusnya juga dimasukkan dalam hierarki peraturan perundang-undangan.

\section{Kedudukan Peraturan Desa}

Melalui UU No. 6 Tahun 2014, Pemerintah telah mengakui Desa telah berkembang dengan berbagai bentuk, sehingga perlu dilindungi dan diberdayakan agar menjadi kuat, maju, mandiri, dan demokratis. Lebih lanjut diatur bahwa jenis peraturan di Desa terdiri atas Peraturan Desa, peraturan bersama Kepala Desa, dan peraturan Kepala Desa. ${ }^{57}$ Hal-hal yang diatur dalam Peraturan Desa berhubungan dengan urusan yang diserahkan kepada Desa, seperti 1. Urusan pemerintahan yang sudah ada berdasarkan hak asal-usul desa; 2. Urusan pemerintahan yang menjadi kewenangan kabupaten/kota yang diserahkan pengaturannya kepada

sebenarnya kurang tepat. Penggunaan kata "peraturan" bukan dalam padanan kata wetgeving atau legislation tetapi sebagai padanan kata regel atau rule, sehingga terkait dengan penamaan, lebih tepat dinamakan "aturan kebijakan” sebagai padanan kata beleidsregel. Lihat Bagir Manan dan Kuntana Magnar, Beberapa Masalah...., Op.Cit., hal. 199.

55 Bagir Manan dalam Arief Christino Soebroto, Kedudukan Hukum....,Op.Cit., hal. 14

56 Hans Kelsen, Pure Theory of Law..., Op. Cit., hal.. 112

$57 \quad$ Pasal 69 ayat (1) UU No. 6 Tahun 2014 tentang Desa desa; 3. Tugas pembantuan dari Pemerintah, Pemerintah Provinsi, dan/atau pemerintah kabupaten/kota; dan 4. Urusan pemerintahan lain yang oleh Peraturan Perundang-undangan diserahkan kepada desa. ${ }^{58}$

Sebagaimana diketahui bahwa Indonesia merupakan negara yang memiliki keberagaman budaya, sumber daya alam, sumber daya manusia, kebutuhan masyarakat, luas wilayah, adat istiadat, agama, sehingga tidak cukup diatur dengan Undang-Undang dan Peraturan Daerah..$^{59}$ Untuk itu, Peraturan Desa maupun Peraturan Kepala Desa diakui sebagai regulasi yang sangat penting untuk mengakomodir local wisdom dan local value yang masih hidup di Indonesia.

Dikarenakan sifat Peraturan Desa dan Peraturan Kepala Desa memiliki sifat yang berlaku umum juga terhadap warga masyarakat yang tinggal di Desa, bukan hanya mengikat terhadap perangkat Desa, maka seharusnya regeling ini juga termasuk ke dalam hierarki peraturan perundang-undangan berdasarkan teori hierarki norma dari Hans Kelsen sebagaimana yang telah dibahas sebelumnya.

Selanjutnya, dalam memformulasikan hierarki perundang-undangan yang tepat, Penulis mencoba memberikan pemikiran baru terkait dengan hierarki norma yang seharusnya diterapkan di Indonesia. Penulis mulai dengan landasan pemikiran dari Maria Farida, setelah itu dimodifikasi dengan membandingkan dengan hierarki norma yang terdapat di Korea Selatan. Maria Farida membedakan peraturan perundang-undangan menjadi dua tingkat yaitu peraturan perundang-undangan tingkat pusat dan peraturan perundang-undangan tingkat daerah, antara lain:

1. Undang-Undang Dasar Negara Republik Indonesia Tahun 1945

2. Peraturan Perundang-Undangan Tingkat Pusat

\footnotetext{
$58 \quad$ Nandang Alamsah Deliarnoor, "Reposisi Peraturan Desa dalam Kajian Undang-Undang Nomor 10 Tahun 2004 dan Undang-Undang Nomor 12 Tahun 2011”, Jurnal Sosial Politik, Vol. 2, No. 1, 2011, hal. 39.

59 Saiful, "Eksistensi Peraturan Desa Pasca Berlakunya Undang-Undang Nomor 12 Tahun 2011", Jurnal Ilmu Hukum Legal Opinion, Edisi 6, Vol. 2, 2014, hal. 6.
} 

a. Undang-Undang dan Peraturan Pemerintah Pengganti Undang- Undang;
b. Peraturan Pemerintah;
c. Peraturan Presiden;
d. Peraturan Menteri;
e. Peraturan Kepala Lembaga Pemerintahan Non Kementerian; dan
f. Peraturan Direktur Jenderal Kementerian.

3. Peraturan Perundang-Undangan Tingkat

\section{Daerah}

a. Peraturan Daerah Provinsi;

b. Peraturan Gubernur;

c. Peraturan Daerah Kabupaten/Kota; dan

d. Peraturan Bupati/Walikota.

Akan tetapi, pendapat Maria Farida tersebut dalam konteks UU No. 10 Tahun 2004 sehingga perlu adanya penyempurnaan kembali. Seperti misalnya, tidak dimasukkannya kedudukan peraturan lembaga tinggi negara (Peraturan DPR, DPD, MPR, BPK, MA, MK, BI) tidak adanya kedudukan peraturan lembaga negara setingkat kementerian dan tidak adanya kedudukan Peraturan Desa. Oleh karena itu, Penulis selanjutnya akan mengkomparasikan dengan pengaturan hierarki norma yang terdapat di negara Korea Selatan. Korea Legislation Research Institute menjelaskan bahwa, "The Korean legislative system consists of the Constitution as the paramount law, Acts to realize the constitutional notions, and administrative legislation including Presidential Decrees, Ordinances of the Prime Minister, Ordinances of Ministries and so forth to effectively implement the Acts. Since statutes form a certain hierarchy, subordinate statutes that are enacted under powers delegated by Acts or are enacted for the purpose of enforcing Acts, are not permitted to contain details in conflict with such Acts."60 Jadi penerapan hierarki norma di Korea Selatan dibagi menjadi kelas-kelas norma yang setingkat, antara lain: ${ }^{61}$

\footnotetext{
60 Korea Legislation Research Institute, Korea Legislative System, https://elaw.klri.re.kr/eng service/struct.do

61 Ministry of Legislation of the Republic of Korea, Overview of Legislation System of the Republic of Korea, hal. 3 http://unpan1.un.org/intradoc/groups/public/documents/ APCITY/UNPAN011552.pdf
}
Class I
: Constitution
Class II
: Acts; Emergency executive order; and Emergency financial and economic executive order; Treaties and conventions
Class III : Presidential Decree; Rules of the National Assembly, Rules of the Supreme Court, and Rules of the Constitutional Court, Etc.
Class IV : Ordinance of the Prime Minister and Ordinance of Ministry
Class V : Administrative Rules (Directives, Regulations, Public Notices, Guidelines, Etc.); Ordinance of Local Government

Berdasarkan pembahasan di atas, sebenarnya dapat diidentifikasi susunan hierarki perundang-undangan di Indonesia untuk masa mendatang, yaitu:

1. Undang-Undang Dasar Negara Republik Indonesia Tahun 1945

2. Peraturan Perundang-Undangan Tingkat Pusat

a. Undang-Undang dan Peraturan Pemerintah Pengganti Undang-Undang;

b. Peraturan Pemerintah;

c. Peraturan Presiden; Peraturan Majelis Permusyawaratan Rakyat, Peraturan Dewan Perwakilan Rakyat, Peraturan Dewan Perwakilan Daerah, Peraturan Mahkamah Agung, Peraturan Mahkamah Konstitusi, dan Peraturan Badan Pemeriksa Keuangan;

d. Peraturan Menteri dan Kepala Lembaga Negara Setingkat Kementerian;
e. Peraturan Kepala Lembaga Pemerintahan Non Kementerian; dan
f. Peraturan Direktur Jenderal Kementerian.

\section{Peraturan Perundang-Undangan Tingkat} Daerah

a. Peraturan Daerah Provinsi; 

b. Peraturan Gubernur;
c. Peraturan Daerah Kabupaten/Kota;
d. Peraturan Bupati/Walikota;
e. Peraturan Desa; dan
f. Peraturan Kepala Desa.

\section{PENUTUP}

Secara legal historis hierarki peraturan perundang-undangan di Indonesia telah mengalami 4 (empat) kali perubahan yaitu melalui Tap MPRS No. XX/MPRS/1966, Tap MPR Nomor III/MPR/2000, UU No. 10 Tahun 2004, dan UU No. 12 Tahun 2011. Masingmasing dari hierarki tersebut memiliki politik hukum dan problematikanya masing-masing, meskipun tentunya memiliki tujuan awal yang sama yaitu untuk menertibkan dan memperbaiki kerancuan dari peraturan sebelumnya. Saat ini di era UU No. 12 Tahun 2011 yang dipandang sebagai undang-undang yang cukup sempurna, masih menimbulkan permasalahanpermasalahan, khususnya berkaitan dengan kedudukan Tap MPR, muatan materi Perpres, kedudukan peraturan-peraturan lembaga negara utama, peraturan menteri dan lembaga negara setingkat kementerian, dan peraturan kepala daerah. Untuk itu, perlu untuk merekonstruksi hierarki peraturan perundangundangan di Indonesia.

Rekonstruksi hierarki peraturan perundang-undangan penting dilakukan agar menjamin konsistensi dan keselarasan normanorma pada berbagai tingkatan peraturan perundang-undangan. Hal ini disebabkan terdapat norma dalam hierarki yang sebenarnya tidak bersifat mengatur (regeling) seperti TAP MPR, sehingga perlu dikeluarkan. Selain itu, terdapat norma di luar hierarki yang sesungguhnya bersifat mengatur (regeling), seperti: peraturan-peraturan lembaga negara utama, peraturan menteri dan lembaga negara setingkat kementerian, dan peraturan kepala daerah, maka perlu dimasukkan. Untuk itu, dalam hasil penelitian ditemukan konstruksi baru hierarki yaitu: 1. Undang-Undang Dasar Negara Republik Indonesia Tahun 1945; 2. Peraturan Perundang-Undangan Tingkat Pusat: a. Undang-Undang dan Peraturan Pemerintah Pengganti Undang-Undang; b. Peraturan Pemerintah; c. Peraturan Presiden, Peraturan Majelis Permusyawaratan Rakyat, Peraturan Dewan Perwakilan Rakyat, Peraturan Dewan Perwakilan Daerah, Peraturan Mahkamah Agung, Peraturan Mahkamah Konstitusi, dan Peraturan Badan Pemeriksa Keuangan; d. Peraturan Menteri dan Lembaga Negara Setingkat Kementerian; e. Peraturan Kepala Lembaga Pemerintahan Non Kementerian; f. Peraturan Direktur Jenderal Kementerian; 3. Peraturan Perundang-Undangan Tingkat Daerah: g. Peraturan Daerah Provinsi; h. Peraturan Gubernur; i. Peraturan Daerah Kabupaten/Kota; j. Peraturan Bupati/Walikota; k. Peraturan Desa; 1. Peraturan Kepala Desa.

\section{DAFTAR PUSTAKA}

\section{Jurnal}

Barlian, Aristo Evandy. "Konsistensi Pembentukan Peraturan Daerah berdasarkan Hierarki Peraturan Perundang-undangan dalam Perspektif Politik Hukum". Fiat Justisia. Vol. 10 No. 4. Oktober-Desember 2016. Pp. 587-814.

Deliarnoor, Nandang Alamsah. "Reposisi Peraturan Desa dalam Kajian UndangUndang Nomor 10 Tahun 2004 dan Undang-Undang Nomor 12 Tahun 2011", Jurnal Sosial Politik, Vol. 2, No. 1, 2011.

Huda, Ni'matul. "Kedudukan Peraturan Daerah dalam Hierarki Peraturan PerundangUndangan”. Jurnal Hukum. Vol. 13 No. 1. Januari 2006. Pp. 27-37.

Irwandi. "Kedudukan Tap MPR dan Implikasinya Terhadap Hierarki Peraturan Perundang-undangan di Indonesia”. Jurnal Inovatif Ilmu Hukum. Vol. 6 No. 2. 2013. Pp. 90-104. 
Liddle, R. William. "Indonesia's Democratic Opening". Journal Government and Opposition. Vol. 34 No. 1. January 1999.

Prasetyaningsih, Rahayu. "menakar kekuasaan Presiden dalam Pembentukan Peraturan Perundang-undangan Menurut UndangUndang Dasar 1945". Padjadjaran Jurnal Ilmu Hukum. Vol. 4 No. 2. 2017. Pp. 263. 280.

Reinstein, Rovert J. "The Limits of Executive Power". American University Law Review. Vol. 59 No. 2. Desember 2009.

Saiful. "Eksistensi Peraturan Desa Pasca Berlakunya Undang-Undang Nomor 12 Tahun 2011", Jurnal Ilmu Hukum Legal Opinion, Edisi 6, Vol. 2, 2014.

Saraswati, Retno. "Perkembangan Pengaturan Sumber Hukum dan Tata Urutan Peraturan Perundang-undangan di Indonesia”. Jurnal Media Hukum. Vol. IX, No. 2. April-Juni 2009. Pp. 1-25.

Simanjuntak, Enrico. "Kewenangan Hak Uji Materil Pada Mahkamah Agung RI". Jurnal Hukum dan Peradilan. Vol. 2 No. 3 November 2013. Pp. 337-356.

Wicaksana, Dian Agung. "Implikasi dan Re-Eksistensi Tap MPR dalam Hierarki Peraturan Perundang-undangan terhadap Jaminan atas Kepastian Hukum yang Adil di Indonesia ", Jurnal Konstitusi. Vol. 10 No. 1. Maret 2013. Pp. 143-178.

\section{Buku}

Al Atok, A. Rosyid. 2015. Konsep Pembentukan Peraturan Perundang-undangan, Malang: Setara Press.

Andrea, S. J. Fockema. 1948. Rechtsgeleerd Handwoordenboek. Groningen/Batavia: J.B. Wolter.

Asshiddiqie, Jimly dan M. Ali Safa'at. 2006. Theory Hans Kelsen Tentang Hukum, Cetakan 1. Jakarta: Sekretariat Jenderal dan Kepaniteraan Mahkamah Konstitusi RI.
Asshiddiqie, Jimly. 2005. Format Kelembagaan Negara dan Pergeseran Kekuasaan Negara dalam UUD 1945. Yogjakarta: FH UII Press.

Asshiddiqie, Jimly. 2007. Pokok-Pokok Hukum Tata Negara Pasca Reformasi, Jakarta: PT Buana Ilmu Populer.

Asshidiqie, Jimly. 2006. Perkembangan dan Konsolidasi Lembaga-Lembaga Negara Pasca Reformasi. Jakarta: Sekretariat Jendral dan Kepaniteraan Mahkamah Konstitusi Republik Indonesia.

Attamimi, A. Hamid S. 1993. Hukum Tentang Peraturan Perundang-Undangan dan Peraturan Kebijakan (Hukum Tata Pengaturan), Pidato purna Bhakti Guru Besar Tetap, Jakarta: Fakultas Hukum Universitas Indonesia.

Attamimi, A. Hamid S. 1990. Peranan Keputusan Presiden Republik Indonesia dalam Penyelenggaraan Pemerintahan Negara: Suatu Studi Analisis Mengenai Keputusan Presiden yang Berfungsi Pengaturan dalam Kurun Waktu Pelita I-IV, Disertasi Hukum. Jakarta: Pascasarjana Universitas Indonesia.

Bagir Manan. 2000. Teori dan Politik Konstitusi, Jakarta: Dirjen DIKTI.

Bagir Manan. 2002. Dasar-Dasar Perundangundangan di Indonesia, Jakarta: Ind. Hill.

Hadjon, Phillipus M. dkk. 2015. Pengantar Hukum Administrasi Indonesia, Yogjakarta: Gadjah Mada University Press.

Huda, Ni'matul dan R. Nazriyah. 2011. Teori dan Pengujian Peraturan PerundangUndangan. Bandung: Nusamedia.

Indrati, Maria Farida, dkk. 2008. Laporan Kompendium Bidang Hukum Peraturan Perundang-Undangan, Jakarta: Pusat Penelitian dan Pengembangan Sistem Hukum Nasional Departemen Hukum dan HAM RI.

Indrati, Maria Farida. 1998. Ilmu PerundangUndangan: Dasar dan Cara Pembentukannya. Yogjakarta: Kanisius. 
Indrati, Maria Farida. 2002. Kedudukan dan Materi Muatan Peraturan Pemerintah Pengganti Undang-Undang, Peraturan Pemerintah dan Keputusan Presiden dalam Penyelenggaraan Pemerintahan Negara di Republik Indonesia, Jakarta: Disertasi Fakultas Hukum Universitas Indonesia.

Indrati, Maria Farida. 2007. Ilmu PerundangUndangan: Dasar dan Cara Pembentukannya, Yogjakarta: Kanisius.

Kelsen, Hans. 1949. General Theory of Law, London: Oxford University Press.

Manan, Bagir dan Kuntana Magnar. 1997. Beberapa Masalah Hukum Tata Negara Indonesia, Bandung: PT Alumni.

MD, Moh Mahfud. 2010. Perdebatan Hukum Tata Negara Pasca Amandemen Konstitusi, Jakarta: Rajawali Press.
Nazriyah, Riri. 2007. MPR RI Kajian Terhadap Produk Hukum dan Prospek di Masa Depan, Yogjakarta: FH UII.

Nursyamsi, Fajri, dkk. 2012. Catatan Kinerja DPR RI Tahun 2011: Legislasi Aspirasi Atau Transaksi? Jakarta: Pusat Studi Hukum dan Kebijakan Indonesia.

Slapper, Gary \& David Kelly. 2003. The English Legal System, Sixth edition, London: Cavendish Publishing Limited.

Soehino. 1981. Hukum Tata Negara Teknik Perundang-undangan, Yogjakarta: Liberty.

Syarief, Amiroedin. 1987. Perundang-undangan: Dasar, Jenis dan Teknis Membuatnya, Jakarta: Bina Aksara. 